\title{
UPGRADING OF K-FELDSPARS OF SAMOTHRAKI ISLAND (NE AEGEAN SEA) IGNEOUS ROCKS FOR USE IN THE CERAMIC AND GLASS INDUSTRY
}

\author{
M. VLAHOU ${ }^{1}$, G. CHRISTOFIDES ${ }^{1}$, K. SIKALIDIS ${ }^{2}$, \\ A. KASSOLI-FOURNARAKI, G. ELEFTHERIADIS
}

\begin{abstract}
K-feldspar phenocrysts from Samothraki island igneous rocks were upgraded by magnetic separation techniques and removal of mica, titanite and harmful oxides present as inclusions in the phenocrysts was achieved. Chemical analyses and technological tests were performed in order to compare free of inclusions and inclusion - bearing K-feldspar samples. Magnetic separation was proved adequate to upgrade the studied samples having particle size -0.5 to $+0.2 \mathrm{~mm}$, resulting to high quality K-feldspars (Total alkalis $>15 \mathrm{wt} \%, \mathrm{Fe}_{2} \mathrm{O}_{3} 0.08$ wt $\%$, $\mathrm{TiO}_{2} 0.04 \mathrm{wt} \%$ ) suitable even for specific ceramic and glass products.
\end{abstract}

KEY WORDS: Northeast Aegean, Samothraki, K-feldspar, upgrade, uses, ceramics, glasses.

\section{INTRODUCTION}

The quality of feldspars as industrial raw materials is highly dependant on their chemical composition, and mainly on their alkalis content. Feldspars are used in the ceramic industry as important fluxing agents. The role of the flux in the ceramic body is to soften in an early stage during firing and to form a glassy matrix that will bond together the other constituents on solidification (Watson 1981). The long fusion range makes high alkali feldspars suitable for the production of porcelain bodies. Higher alkalis content results to greater fluxing action, and consequently lower softening temperature and melting point. According to Deer et al. (1992) the potassium end-member $\left(\mathrm{KAlSi}_{3} \mathrm{O}_{8}\right)$, under anhydrous conditions and pressure of $1 \mathrm{~atm}$, has a melting point of $1155^{\circ} \mathrm{C}$. The sodium end member $\left(\mathrm{NaAlSi}_{3} \mathrm{O}_{8}\right)$ under the same conditions melts at $1118^{\circ} \mathrm{C}$. The $\mathrm{K} 2 \mathrm{O} / \mathrm{Na}_{2} \mathrm{O}$ ratio of the feldspar used as flux, affects the firing temperature of the ceramic body and the degree of sintering of the product. The increase in the amount of $\mathrm{K}$-feldspar against $\mathrm{Na}$-feldspar in a ceramic body increases the refractoriness of the material produced (Bolger 1995a). During thermal treatment, the contained $\mathrm{Al}_{2} \mathrm{O}_{3}$ assists the formation of mullite, which acts as matrix reinforcement improving the product's compression strength (Harada et al. 1996). Sintering, whiteness, translucency, chipping, peeling, and crazing are some of the technological characteristics of ceramics that are influenced by feldspars (Sikalidis et al. 1997).

In the glass industry feldspars are used as a source of aluminium and silica (Harben 1992) but their fluxing ability is also useful. Feldspars have a long and low vitrification curve that allows a high degree of control on the product. Aluminium in glass acts as a stabilizer improving the thermal, chemical, scratching resistance, as well as the crushing and compressing strength (Bolger 1995a). It also inhibits vitrification and increases viscosity during glass forming process (Watson 1981, Harben \& Bates 1990, Potter 1997).

Generally, feldspars quality is connected to the ceramic or glass product specifications. They can be classified into different qualities mainly according to their $\mathrm{K}_{2} \mathrm{O} / \mathrm{Na}_{2} \mathrm{O}$ ratio, and to their iron and titanium as well as other colouring oxides content, which should not exceed certain percentages. Feldspars with high $\mathrm{K}_{2} \mathrm{O}$ content, and chemistry that does not deviate significantly from the theoretical end member, are considered of premium quality. Special care should be taken for the refractory minerals that are present as inclusions in natural occurring feldspars due to anomalies in the vitrification curve and specs they could attribute to the product. In addition, since they are mainly used as fluxing agents, the grain size distribution is also very important (Bolger 1995b).

This study is an effort to upgrade the K-feldspars of Samothraki igneous rocks by magnetic separation as a simple and economic method in dry state, towards their uses in ceramic and glass industry. The results were verified by chemical analyses and technological tests on treated samples and compared with similar results of

1. Aristotle University of Thessaloniki, Dept. Mineralogy-Petrology-Economic Geology, 54006 Thessaloniki, Macedonia, Greece.

2. Aristotle University of Thessaloniki, Dept. of Chemical Engineering, 54006 Thessaloniki, Macedonia, Greece. 


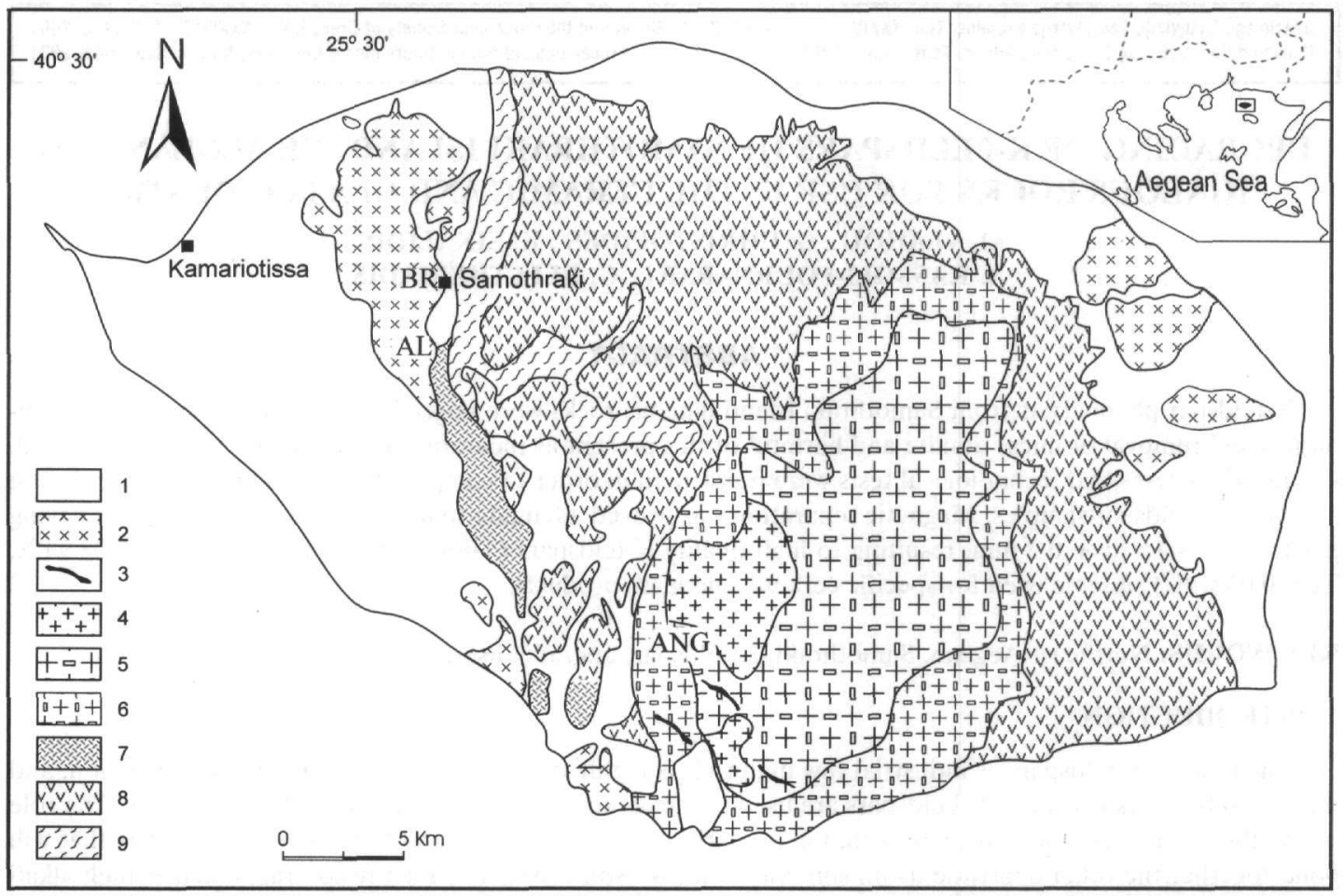

Fig. 1. Schematic geological map of the Samothraki island according to Christofides et al. (2000). 1:TertiaryQuaternary sedimentary rocks, 2:Tertiary volcanics, 3:Micro-granite, 4: Biotite-granite, 5:Porphyritic quartzmonzonite to granite, 6:Porphyritic micro-quartz-monzonite to micro-granite, 7:Gabbrodiorite, 8:Ophiolites, 9:Basement rocks. $B R=$ Brehos, $A L=$ Alonia, $A N G=$ Anginaros.

non-treated (inclusion - bearing) samples (Vlahou et al. 2000).

\section{GEOLOGICAL AND PETROGRAPHICAL DATA}

The Samothraki island is situated in the northeastern Aegean (Fig. 1) and geotectonically belongs to the Circum-Rhodope Belt (Kaufmann et al. 1976). The Mesozoic basement consists of low grade metamorphic rocks comprising argillaceous and quartzose slates, schistose greywackes and marbles (Davis 1963, Heimann 1967). In normal contact with the basement is the Upper Jurassic ophiolitic unit (Tsikouras et al. 1990) that comprises gabbro, diorite, diabase and basalt. The ophiolitic unit is overlain discordantly by Eocene sedimentary rocks.

The central and norhteastern part of the island is occupied by the Miocene Samothraki granite. The granite is chemically quite homogeneous but on the basis of mineralogical and textural criteria it can be divided into four main types; porphyritic micro-quartz-monzonite to micro-granite, porphyritic quartz-monzonite to granite, biotite-granite and micro-granite (Christofides et al. 2000). Generally, the pluton is characterized by a strongly porphyritic texture with K-feldspar megacrysts in the periphery of the body opposed to the center where it is mostly equigranural. The $\mathrm{K}$-feldspar phenocrysts that can measure more than $8 \mathrm{~cm}$ in length, are present in more than $10 \%$ in the porphyritic micro-quartz-monzonite and in smaller but still significant amounts in the porphyritic quartz-monzonite. Other minerals present are plagioclase, quartz, biotite, and hornblende.

The above K-feldspar megacrysts are white to pale greyish in colour and very often have inclusions of plagioclase, quartz, biotite, hornblende, and traces of titanite. The feldspar reserves calculated for the minimum percent $(10 \%)$ only for the porphyritic micro-quartz-monzonite and only for the apparent deposits are over $15,000 t$.

Volcanic domes of Miocene age (Eleftheriadis et al., 1994) are situated mainly NW of the pluton intruding older formations. Chemically, these rocks are intermediate to acid, showing strongly porphyritic texture with characteristic phenocrysts of K-feldspars reaching $10 \mathrm{~cm}$ in length. Mineral constituents include sanidine, 
plagioclase, quartz, and biotite. Hornblende is also present in significant amounts only in certain areas, while augite is also present in smaller amounts (Eleftheriadis et al. 1989, 1993). Sanidine phenocrysts are euhedral; white to pink with inclusions of plagioclase, biotite, hornblende, opaque minerals, and traces of pyroxene and titanite. Apparent feldspar reserves calculated only for the two domes of Brehos and Tourli are more than $5,000 \mathrm{t}$ and 2,000t respectively, while the reserves of other locations exceed greatly the previous numbers. Zeolite and some calcite are also present as alteration products.

\section{MATERIALS AND METHODS}

Two samples KF1 and KF2 of feldspar megacrysts from Samothraki volcanic rocks of Brehos dome (BR, Fig.1) and another one, KF3, from the porphyritic micro-quartz-monzonite of Anginaros area (ANG, Fig.1) were selected. KF1 represents unaltered crystals, whereas KF2 represents partly zeolitized crystals of K-feldspars hosted in the dacitic dome. An altered whole rock sample MAL104, from the locality Alonia (AL, Fig.1) is also studied and compared to the previous. It is an altered dacite that consists of plagioclase, quartz, sanidine, hornblende, and biotite partly opacitized while titanite and opaque minerals are present as accessories.

The above samples were crushed and sieved. The fraction of -0.5 to $+0.2 \mathrm{~mm}$ was treated by a Frantz isodynamic magnetic separator to eliminate basically the femic inclusions found in the megacrysts. The current intensity used was 0.9 amps with an inclination of $10^{\circ}$, in accordance to Hutchison (1974). The free from inclusions material was then pulverized in a tungsten carbide barrel gyro-mill. Chemical characteristics of this material were determined by a Perkin Elmer 5000 Atomic Absorption Spectrophotometer.

For the study of technological characteristics, specimens were prepared by powder pressing at $500 \mathrm{kgf} / \mathrm{cm}^{2}$ in a cylindrical mold. The specimens were subjected to thermal treatments for three hours at the peak temperatures 1000, 1050, 1100, 1150 and $1200^{\circ} \mathrm{C}$. Technological tests and measurements, according to the American Standard Testing Methods (ASTM) and the English China Clays Co. (1977) were followed, and the degree of sintering, firing shrinkage, water absorption and whiteness of the specimens was determined.

Table 1. Chemical analyses (wt\%) of K-feldspar samples of Samothraki igneous rocks non-treated and treated by magnetic separator.

\begin{tabular}{l|cc|c|c|c|c|cc}
\hline & \multicolumn{2}{|c|}{ KF1 } & \multicolumn{2}{c|}{ KF2 } & \multicolumn{2}{c|}{ KF3 } & \multicolumn{2}{c}{ MAL104 } \\
\hline \multirow{2}{*}{} & Non-treated & Treated & Non-treated & Treated & Non-treated & Treated & Non-treated & Treated \\
\cline { 2 - 9 } $\mathrm{SiO}_{2}$ & 64,72 & 65,00 & 63,85 & 64,74 & 66,89 & 65,60 & 66,78 & 67,44 \\
$\mathrm{TiO}_{2}$ & 0,28 & 0,09 & 0,34 & 0,06 & 0,19 & 0,07 & 1,02 & 0,08 \\
$\mathrm{Al}_{2} \mathrm{O}_{3}$ & 17,85 & 18,39 & 17,56 & 18,24 & 17,15 & 18,13 & 14,20 & 18,35 \\
$\mathrm{Cr}_{2} \mathrm{O}_{3}$ & $*$ & - & $*$ & - & $*$ & - & $*$ & - \\
$\mathrm{Fe}_{2} \mathrm{O}_{3}$ & 0,42 & 0,17 & 0,69 & 0,16 & 0,39 & 0,15 & 3,10 & 0,29 \\
$\mathrm{MnO}$ & 0,014 & $*$ & 0,015 & $*$ & 0,007 & $*$ & 0,167 & $*$ \\
$\mathrm{MgO}$ & 0,08 & 0,10 & 0,10 & 0,11 & 0,09 & 0,10 & 1,12 & 0,13 \\
$\mathrm{CaO}$ & 1,34 & 1,65 & 1,60 & 1,89 & 0,96 & 1,55 & 3,30 & 4,05 \\
$\mathrm{Na} 2 \mathrm{O}$ & 3,65 & 3,47 & 3,82 & 3,49 & 3,43 & 3,29 & 4,25 & 4,16 \\
$\mathrm{~K}_{2} \mathrm{O}$ & 10,85 & 10,62 & 10,67 & 10,37 & 10,79 & 10,87 & 3,86 & 3,87 \\
$\mathrm{P}_{2} \mathrm{O}_{5}$ & 0,055 & 0,05 & 0,055 & 0,05 & 0,083 & 0,09 & 0,220 & 0,10 \\
$\mathrm{LOI}$ & 0,59 & 0,85 & 1,06 & 0,69 & 0,24 & 0,10 & 1,94 & 1,90 \\
& & & & & & & & \\
$\mathrm{Total}$ & 99,85 & 100,39 & 99,76 & 99,80 & 100,22 & 99,95 & 99,96 & 100,37 \\
\hline $\mathrm{K}_{2} \mathrm{O}+\mathrm{Na}_{2} \mathrm{O}$ & 14,5 & 14,1 & 14,5 & 13,9 & 14,2 & 14,2 & 8,1 & 8,0 \\
$\mathrm{~K}_{2} \mathrm{O} / \mathrm{Na}_{2} \mathrm{O}$ & 3,0 & 3,1 & 2,8 & 3,0 & 3,1 & 3,3 & 0,9 & 0,9 \\
\hline
\end{tabular}

\section{RESULTS AND DISCUSSION}

Chemical analyses of the studied samples are given in Table 1. Free silica calculated, being in very low percentage is not affected by magnetic treatment (Hutchinson, 1974) and is known that is needed anyway in a ceramic batch. The alkalis content shows a small change that could be attributed to the removal of mica, amphiboles, titanite and opaque minerals and the subsequent normalization of the analysis. This change however is in the range of analytical error. The $\mathrm{K}_{2} \mathrm{O}+\mathrm{Na}_{2} \mathrm{O}$ sum decreases slightly, while their ratio somewhat increases in all samples. Potassium affects the range of softening temperature and increases the viscosity of the produced glassy matrix affecting the mechanical strength and the distortion of the ceramic product. The total alkalis content determined is acceptable for most applications in the ceramic and glass industry. 

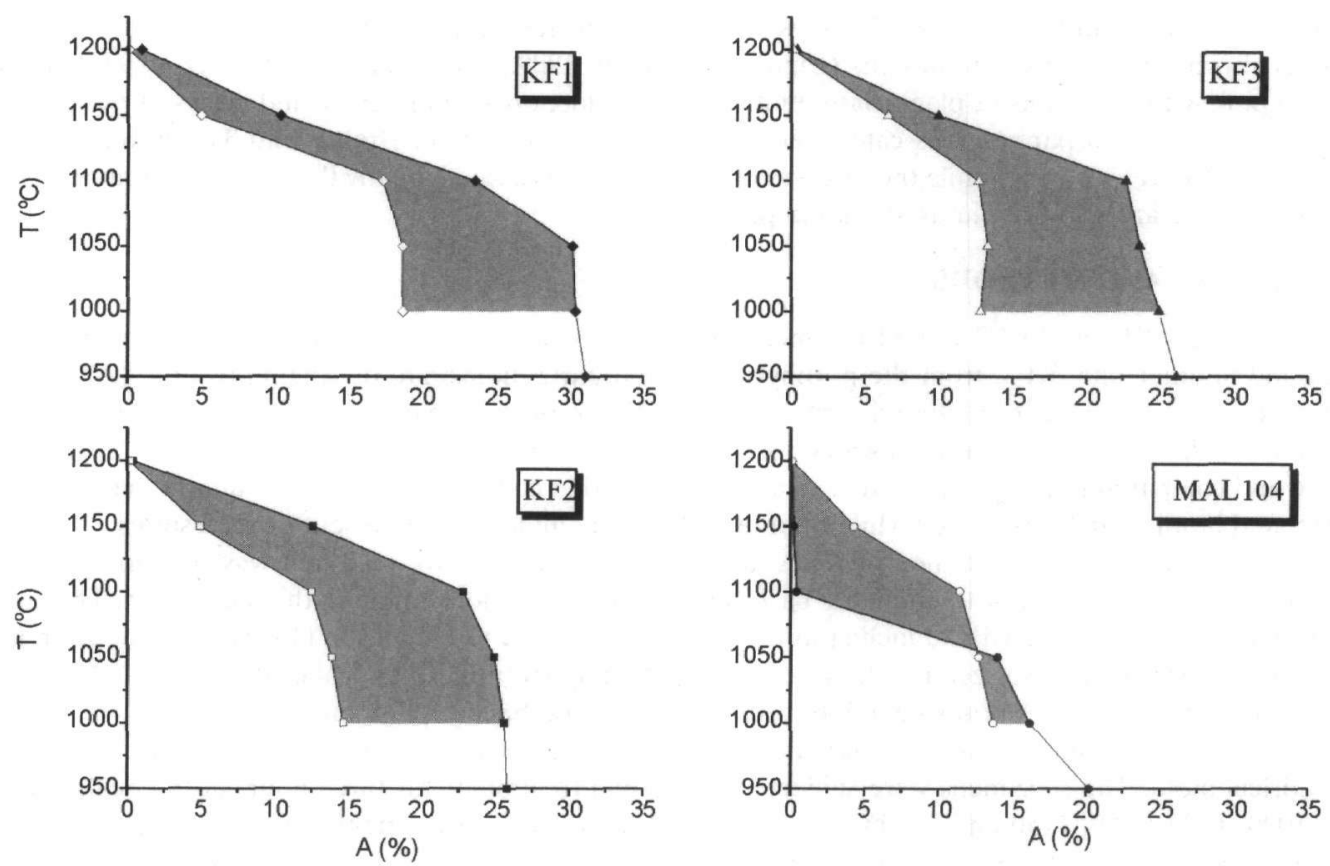

Fig. 2. Effect of temperature $\left(T^{\circ} \mathrm{C}\right)$ on water absorption $(A \%)$ of the four specimens studied from Samothraki igneous rocks. Open symbols $=$ treated material, closed symbols $=$ non-treated material.

Magnetic separation was found to be effective in eliminating $\mathrm{MnO}$, while $\mathrm{MgO}$ content showed no change in the mineral samples, where in the whole rock sample a striking decrease was observed. $\mathrm{Fe}_{2} \mathrm{O}_{3}$ content dropped after magnetic treatment close to the limit of $0.1 \mathrm{wt} \%$ needed for non-coloured glass products (Bolger, 1995b) and for ceramic whitewares and porcelain as well; while $\mathrm{TiO}_{2}$ content dropped from about 0.3 wt $\%$ below 0.1 $\mathrm{wt} \%$ in all samples. In specific white ceramic products a requirement of $\mathrm{TiO}_{2}$ content $0.03 \mathrm{wt} \%$ is generally acceptable (Sikalidis, 1998). In general, the decrease observed in $\mathrm{Fe}_{2} \mathrm{O}_{3}, \mathrm{TiO}_{2}$, and $\mathrm{MnO}$ suggests that the colouring oxides are mainly attributed to the femic inclusions present in the megacrysts (Vlahou et al. 2000). $\mathrm{Al}_{2} \mathrm{O}_{3}$ content is high in all samples and ranges from 18.13 to $18.39 \mathrm{wt} \%$.

The particle size distribution of the milled powder used for the technological tests was found to be under $75 \mu \mathrm{m}$ in $90 \%$ for all samples.

Technological characteristics values of the Samothraki feldspar specimens are given in Table 2 and the effect of temperature on water absorption is presented in figure 2 . In the same figure differences between treated and non-treated specimens are shown.

Table 2. Water absorption and whiteness values of the samples investigated.

\begin{tabular}{|c|c|c|c|c|c|}
\hline & & KF'1 & KF2 & $\mathrm{KF} 3$ & MAL104 \\
\hline \multicolumn{6}{|c|}{ Water absorption (wt $\frac{8}{8}$ ) } \\
\hline \multirow{5}{*}{ Thermal treatment at } & $1000^{1} \mathrm{C}$ & 17,1 & 14,7 & 12,8 & 13,7 \\
\hline & $1050^{\ddot{2}} \mathrm{C}$ & 18,7 & 13,9 & 13,3 & 12,7 \\
\hline & $1100^{13} \mathrm{C}$ & 17,4 & 12,5 & 12,7 & 11,5 \\
\hline & $1150^{I 2} \mathrm{C}$ & 5,0 & 4,9 & 6,6 & 4,3 \\
\hline & $1200^{2} \mathrm{C}$ & 0,0 & 0,2 & 0,1 & 0,1 \\
\hline \multicolumn{6}{|c|}{ Whiteness ( $\%$ of $\mathrm{MgO}$ ) } \\
\hline \multirow{2}{*}{\multicolumn{2}{|c|}{$\begin{array}{l}\text { Before thermal treatment } \\
\text { Thermal treatment at } 1200^{\mathrm{C}} \mathrm{C}\end{array}$}} & 84,5 & 83,6 & 83,1 & 81,2 \\
\hline & & 51,2 & 83,6 & 83,0 & 79,5 \\
\hline
\end{tabular}


Sindering takes place after thermal treatment at around $1050^{\circ} \mathrm{C}$. Consequently, above this temperature the water absorption of both treated and non-treated specimen drops abruptly until it reaches zero values (Fig. 2). The decreasing rate of water absorption in percentage for the non-treated specimens is higher, indicating that the presence of inclusions fasten sintering process. Above $1150^{\circ} \mathrm{C}$, water absorption values of both treated and non-treated specimens converge until they reach zero values at $1200^{\circ} \mathrm{C}$.

Whiteness values, as percentage from the "absolute white" of a $\mathrm{MgO}$ standard, of treated powders of $\mathrm{K}$ feldspar samples are given in Table 2. Significant improvement compared to data from non-treated powders (Vlahou et al. 2000), was obtained in all samples. As it was expected the comparative difference in values of the whole rock sample MAL104 was more significant. The whiteness values of specimens prepared with magnetically separated materials after thermal treatment (Table 2) are accepted for most applications. The lower value of $\mathrm{KF} 1$ specimen is attributed mainly to the higher content of colouring materials.

\section{CONCLUSIONS}

Megacrysts of K-feldspars from Samothraki igneous rocks were found to have elevated values of colouring oxides, like $\mathrm{Fe}_{2} \mathrm{O}_{3}$ and $\mathrm{TiO}_{2}$ (Vlahou et al. 2000). These oxides were mainly attributed to the femic inclusions present in the megacrysts. Upgrading of K-feldspars by magnetic separation gave rise to a material of good whiteness, low water absorption, and sindering that renders them useful for ceramics fired at temperatures of P.C.E 08 to 01 British Cones and in some cases 1 to 5 British Cones. In conclusion, magnetic separation of the felsic inclusions was found to be adequate to produce a material of improved quality having chemical and technological characteristics accepted for all conventional applications in ceramic and glass industry.

Upgrading of the whole rock sample by magnetic separation produced a material of very good technological characteristics and similar quality to that of the other three specimens.

\section{ACKNOWLEDGEMENTS}

We owe thanks to Dr. T. Hatzinikolaou of Microfine Hellas A.M.E. for helping in the whiteness measurements of our samples.

\section{REFERENCES}

American Standard Testing Methods D-422/72, C-775-79, C-689-80, C-369, C-326-76, C-373-77\& 77a, C-24-79

BOLGER R. (1995a) Raw materials for pigments fillers and extenders. An IM Consumer survey. Ed. R.L. Bolger and M.J. O'Driscoll, Industrial Minerals Publ.

BOLGER R. (1995b) Feldspar and nepheline syenite, Turkish delight in export sales. Ind. Miner., 332, 25-45.

CHRISTOFIDES G., ELETHERIADIS G., ESSON J. (1990) Preliminary results on the magmatic evolution of the island of Samothraki granite (N. Greece). Geolog. Rodop., 2, 213-226.

CHRISTOFIDES G., ELEFTHERIADIS G., ESSON J. SOLDATOS T., KORONEOS A., BROECKER M. (2000) The evolution of the Samothraki granitic pluton (N. Aegean sea, Greece): geochronology, chemical and isotopic constraints for AFC modeling. Proc. $3^{\text {rd }}$ Int. Conf. Geol. Eastern Mediter, eds. Panayides I., Xenophontos C. and Malpas J., Nicosia, Cyprus.

DAVIS E. (1963) Geological structure of the island of Samothraki. Annal. Geol. Pays Hell., 14, 133-188 (in greek).

DEER W.A., HOWIE R.A., ZUSSMAN J. (1992) An introduction to the rock forming minerals. Longman Group Ltd.

ELEFTHERIADIS G., ESSON J., CHRISTOFIDES G. (1989) Petrology and geochemistry of Tertiary volcanics from Samothraki (N. Greece). Bull. Geol. Soc. Greece, 23[2], 429-442.

ELEFTHERIADIS G., ESSON J., SOLDATOS T., CHRISTOFIDES G.(1993) Magmatic evolution of the Tertiary volcanic rocks of Samothraki island (Thrace, N. Greece). Honorary Publication A. Panagos Vol. A Ed. Athens Polytechnical School.

ELEFTHERIADIS G., PE-PIPER G., CHRISTOFIDES G., SOLDATOS T., ESSON J. (1994) K-Ar dating of the Samothraki volcanic rocks, Thrace, North-Eastern Aegean (Greece). Bull. Geol. Soc. Greece, 30[1], $205-212$.

ENGLISH CHINA CLAYS INTERNATIONAL PUBLICATIONS (1977) Routine Testing of Ceramic Materials, Roadway Smith Ltd, Bournemouth.

HARADA R., SUGIYAMA N., ISHIDA H.(1996) $\mathrm{Al}_{2} \mathrm{O}_{3}$-strengthened feldspathic porcelain bodies: Effects of the amount and particle size of alumina. Ceram. Eng. Sci. Proc., 17, 88-98.

HARBEN P. (1992) The industrial minerals handybook. A guide to markets, specifications, and prices. Ind. Miner. 
Divis. Metal Bull. PLC, London.

HARBEN P.W., BATES R.L. (1990) Industrial Minerals. Geology and World Deposits. Ind. Miner. Divis. Metal Bull. PLC, London.

HUTCHISON C.S. (1974) Laboratory handbook of petrograpic techniques. John Wiley \& sons, Inc., New York. HEIMANN K. (1967) Ueber das Alter praetertiaerer Gesteine des Nordwestteils der Insel Samothraki (Griechenland). Proc. Acad. Athens, 42, 153-160.

KAUFMANN G., KOCKEL F., MOLLAT H. (1976) Notes on the stratigraphic and paleogeographic position of the Svoula formation in the innermost zone of the Hellenides (Northern Greece). Bull. Soc. Geol. France, 18, 225-230.

POTTER M.J. (1997) Feldspar. Amer. Ceram. Soc. Bull., 76[6], 96-97.

SIKALIDIS C. (1998) Inorganic industrial raw materials. A.U.Th., Thessaloniki, 76.

SIKALIDIS C.A., KASSOLI-FOURNARAKI A., FILIPPIDIS A. (1997) Feldspars from the Paranesti Pegmatite veins (N.E. Greece) for the ceramic and glass industry. Interceram, 46, 227-231.

TSIKOURAS B., PE-PIPER G., HATZIPANAGIOTOU K. (1990) A new date for the ophiolite on the northeastern margin of the Vardar zone, Samothraki, Greece. N. Jb. Miner. Mh., 11, 521-527.

VLAHOU M., CHRISTOFIDES G., SIKALIDIS C., KASSOLI-FOURNARAKI A., ELEFTHERIADIS G. (2000) Investigation of some characteristics of K-feldspars from Samothraki igneous rocks for use in the ceramic industry. Interceram, 49, 290-297.

WATSON I. (1981) Feldspathic fluxes - the rivalry reviewed. Ind. Miner., 163, 21- 45. 